\title{
PENINGKATAN PRESTASI BELAJAR MATEMATIKA MELALUI METODE PEMBELAJARAN KOOPERATIF MODEL STAD (STUDENT TEAMS ACHIEVEMENT DIVISION)
}

\author{
Suhari \\ SMP Negeri 1 Paciran. Kab. Lamongan
}

\begin{abstract}
The purpose of this research is (1) to describe the improvement of Mathematics learning achievement after the implementation of cooperative learning, (2) to describe the influence of learning motivation after applying cooperative learning, (3) to give an accurate learning method in improving student achievement and make students active in teaching and learning activities. This research uses action research for three rounds. each round consists of four stages: design, activity and observation, reflection, and revision. From the analysis result, it is found that the students' learning achievement has improved from cycle I to cycle III, that is cycle I (68,42\%), cycle II $(81,58 \%)$, cycle III (94,74\%). The conclusion of this research is cooperative learning method can have a positive effect on student achievement and motivation of IX class SMP Negeri 1 Paciran.
\end{abstract} Keywords: mathematics, cooperative learning method

Abstrak: Tujuan dari penelitian ini adalah (1) ingin mendeskripsikan peningkatan prestasi belajar Matematika setelah diterapkannya pembelajaran kooperatif, (2) ingin mendeskripsikan pengaruh motivasi belajar Matematika setelah diterapkannya pembelajaran kooperatif, (3) memberikan gambaran metode pembelajaran yang tepat dalam upaya meningkatkan prestasi belajar siswa dan menjadikan siswa aktif dalam kegiatan belajar mengajar. Penelitian ini menggunakan penelitian tindakan (action research) sebanyak tiga putaran. setiap putaran terdiri dari empat tahap: rancangan, kegiatan dan pengamatan, refleksi, dan revisi. Dari hasil analisis didapatkan bahwa prestasi belajar siswa mengalami peningkatan dari siklus I sampai siklus III, yaitu siklus I $(68,42 \%)$, siklus II $(81,58 \%)$, siklus III $(94,74 \%)$. Simpulan dari penelitian ini adalah metode pembelajaran kooperatif dapat berpengaruh positif terhadap prestasi dan motivasi belajar siswa kelas IX SMP Negeri 1 Paciran.

Kata kunci: matematika, metode pembelajaran kooperatif

\section{PENDAHULUAN}

Guru memiliki peranan yang sangat penting dalam menentukan kuantitas dan kualitas pengajaran yang dilaksanakan. Oleh sebab itu, guru harus memikirkan dan membuat perencanaan secaraa seksama dalam meningkatkan kesempatan belajar bagi siswanya dan memperbaiki kualitas mengajarnya.

Hal ini menuntut perubahanperubahan dalam mengorganisasikan kelas, penggunaan metode mengajar, strategi belajar mengajar, maupun sikap dan karakteristik guru dalam mengelola 
proses belajar mengajar. Guru berperan sebagai pengelola proses belajarmengajar, bertindak sebagai fasilitor yang berusaha mencipatakan kondisi belajar mengajar yang efektif, sehingga memungkinkan proses belajar mengajar, mengembangkan bahan pelajaran dengan baik, dan meningkatkan kemampuan siswa untuk menyimak pelajaran dan menguasai tujuan-tujuan pendidikan yang harus mereka capai. Untuk memenuhi hal tersebut di atas, guru dituntut mampu mengelola proses belajar mengajar yang memberikan rangsangan kepada siswa, sehingga ia mau belajar karena siswalah subyek utama dalam belajar.

Mengajar adalah membimbing belajar siswa sehingga ia mampu belajar. Dengan demikian aktifitas siswa sangat diperlukan dalam kegiatan belajarmengajar sehingga siswalah yang seharusnya banyak aktif, sebab siswa sebagai subyek didik adalah yang merencanakan, dan ia sendiri yang melaksanakan belajar. Pada kenyataan, di sekolah-sekolah seringkali guru yang aktif, sehingga siswa tidak diberi kesempatan untuk aktif.

Kegiatan belajar bersama dapat membantu memacu belajar aktif. Kegiatan belajar dan mengajar di kelas memang dapat menstimulasi belajar aktif. Namun kemampuan untuk mengajar melalui kegiatan kerjasana kelompok kecil akan memungkinkan untuk menggalakkan kegiatan belajar aktif dengan cara khusus. Apa yang didiskusikan siswa dengan temantemannya dan apa yang diajarkan siswa kepada teman-temannya memungkinkan mereka untuk memperoleh pemahaman dan penguasaan materi pelajaran.

Pembelajaran Matematika tidak lagi mengutamakan pada penyerapan melalui pencapaian informasi, tetapi lebih mengutamakan pada pengembangan kemampuan dan pemrosesan informasi. Untuk itu aktifitas peserta didik perlu ditingkatkan melalui latihan-latihan atau tugas dengan bekerja dalam kelompok kecil dan menjelaskan ide-ide kepada orang lain. (Hartoyo, 2000:24).

Langkah-langkah tersebut memerlukan partisipasi aktif dari siswa. Untuk itu perlu ada metode pembelajaran yang melibatkan siswa secaraa langsung dalam pembelajaran. Adapun metode yang dimaksud adalah metode pembelajaran kooperatif. Pembelajaran kooperatif adalah suatu pengajaran yang melibatkan siswa bekerja dalam kelompok-kelompok untuk menetapkan tujuan bersama. (Felder, 1994:2).

Pembelajaran kooperatif lebih menekankan interaksi antar siswa. Dari sini siswa akan melakukan komunikasi aktif dengan sesama temannya. Dengan komunikasi tersebut diharapkan siswa dapat menguasai materi pelajaran dengan mudah karena "siswa lebih mudah memahami penjelasan dari kawannya dibanding penjelasan dari guru, karena taraf pengetahuan serta pemikiran mereka lebih sejalan dan sepadan". (Sulaiman dalam Wahyuni 2001: 2).

Pete Tschumi dari Universitas Arkansas Little Rock memperkenalkan suatu ilmu pengetahuan pengantar pelajaran komputer selama tiga kali, yang pertama siswa bekerja secaraa individu, dan dua kali secaraa kelompok. Dalam kelas pertama hanya $36 \%$ siswa yang mendapat nilai $\mathrm{C}$ atau lebih baik, dan dalam kelas yang bekerja secaraa kooperatif ada $58 \%$ dan $65 \%$ siswa yang mendapat nilai $\mathrm{C}$ atau lebih baik (Felder, 199: 14).

Berasarkan paparan tersebut di atas, maka peneliti ingin mencoba melakukan penelitian dengan judul " Peningkatan Prestasi Belajar Matematika Melalui Metode Pembelajaran Kooperatif Model STAD (Student Teams Achievement Division) Pada Siswa Kelas IX SMP Negeri 1 Paciran Tahun Pelajaran 2008 2009 “. 
Penelitian ini bertujuan ingin mengetahui hal-hal berikut:

(1) peningkatan prestasi belajar Matematika setelah diterapkannya pembelajaran kooperatif model STAD pada siswa IX SMP Negeri 1 Paciran tahun pelajaran 2008/ 2009.

(2) pengaruh motivasi belajar Matematika setelah diterapkannya pembelajaran kooperatif model STAD pada siswa kelas IX SMP Negeri 1 Paciran tahun pelajaran 2008/2009

(3) gambaran tentang metode pembelajaran yang tepat dalam upaya meningkatkan prestasi belajar siswa dan menjadikan siswa menjadi aktif dalam kegiatan belajar mengajar.

\section{METODE PENELITIAN}

Penelitian ini merupakan penelitian tindakan (action research), karena penelitian dilakukan untuk memecahkan masalah pembelajaran di kelas. Penelitian ini juga termasuk penelitian deskriptif, sebab menggambarkan bagaimana suatu teknik pembelajaran diterapkan dan bagaimana hasil yang diinginkan dapat dicapai.

Menurut Sukidin dkk. (2002:54) ada 4 macam bentuk penelitian tindakan yaitu: (1) penelitian tindakan guru sebagai peneliti, (2) penelitian tindakan kolaboratif, (3) penelitian tindakan simultan terintegratif, dan (4) penelitian tindakan sosial eksperimental.

Keempat bentuk penelitian tindakan di atas, ada persamaan dan perbedaannya. Menurut Oja dari SMA 1 yang sebagaimana dikutip oleh Kasbolah, (2000) (dalam Sukidin, dkk. 2002 : 55), ciri-ciri dari setiap penelitian tergantung pada : (1) tujuan utamanya atau pada tekanannya, (2) tingkat kolaborasi antara pelaku peneliti dan peneliti dari luar, (3) proses yang digunakan dalam melakukan penelitian, dan (4) hubungan antar proyek dengan sekolah.
Dalam penelitian ini menggunakan bentuk guru sebagai peneliti, dimana guru sangat berperan sekali dalm proses penelitian tindakan kelas. Dalam bentuk ini, tujuan utama penelitian tindakan kelas ialah untuk meningkatkan praktikpraktik pembelajaran di kelas. Dalam kegiatan ini guru terlibat langsung secara penuh dalam proses perencanaan, tindakan, observasi, dan refleksi. Kehadiran pihak lain dalam penelitian ini perananya tidak dominan dan sangat kecil.

Penelitian ini mengacu pada perbaikan pembelajaran yang berkesinambungan. Kemmis dan Tagart (1988 :14) menyatakan bahwa model penelitian tindakan adalah berbentuk spiral. Tahapan penelitian tindakan pada suatu siklus meliputi perencanaan atau pelaksanaan observasi dan refleksi. Siklus ini berlanjut dan akan dihentikan jika sesuai dengan kebutuhan dan dirasa sudah cukup.

Tempat penelitian adalah tempat yang digunakan dalam melakukan penelitian untuk memperoleh data yang diinginkan. Penelitian ini bertempat di SMP Negeri 1 Paciran. Waktu penelitian adalah waktu berlangsungnya penelitian atau saat penelitian ini dilangsungkan. Penelitian ini dilaksanakan pada bulan Juli sampai September 2008 semester ganjil tahun pelajaran $2008-2009$.

Subjek penelitian adalah siswa- siswi kelas IX SMP Negeri 1 Paciran tahun pelajaran 2008 - 2009. Pada pokok bahasan Kesebangunan Bangun Datar.

Alat pengumpul data dalam penelitian ini adalah tes buatan guru yang fungsinya adalah: (1) Untuk menentukan seberapa baik siswa telah menguasai bahan pelajaran yang telah diberikan dalam waktu tertentu;(2) Untuk menentukan apakah suatu tujuan telah tercapai; dan (3) Untuk memperoleh suatu nilai (Arikunto, Suharismi, 2002:

19). Sedangkan tujuan dari tes adalah 
untuk mengetahui ketuntasan belajar siswa secaraa individual maupun secaraa klasikal. Disamping itu untuk mengetahui letak kesalahan-kesalahan yang dilakukan siswa kelas IX SMP Negeri 1 Paciran, sehingga dapat dilihat dimana kelemahannya, khususnya pada bagian mana TPK/ Indikator yang belum tercapai. Untuk memperkuat data yang dikumpulkan, maka juga digunakan metode observasi (pengamatan) yang dilakukan oleh teman sejawat untuk mengetahui dan merekam aktifitas guru dan siswa dalam proses belajar mengajar.

Untuk mengetahui kefektivan suatu metode dalam kegiatan pembelajaran perlu diadakan analisis data. Pada penelitian ini menggunakan teknik analisis dekriptif kualitatif, yaitu suatu metode penelitian yang bersifat menggambarkan kenyataan atau fakta sesuai dengan data yang diperoleh dengan tujuan untuk mengetahui prestasi belajar yang dicapai siswa, juga untuk memperoleh respon siswa terhadap kegiatan pembelajaran serta aktivitas siswa selama proses pembelajaran.

Untuk menganalisi tingkat keberhasilan atau presentase keberhasilan siswa setelah proses belajar mengajar setiap putarannya dilakukan dengan cara memberikan evaluasi berupa soal tes tertulis paa setiap akhir putaran. Analisis ini dihitung dengan menggunakan statistik sederhana.

\section{HASIL PENELITIAN DAN \\ PEMBAHASAN \\ Analisis Hasil Penelitian \\ Siklus I \\ Tahap Perencanaan}

Pada tahap ini peneliti mempersiapkan perangkat pembelajaran yang terdiri dari rencana pelajaran 1, soal tes formatif I dan alat-alat pengajaran yang mendukung. Selain itu juga dipersiapkan lembar observasi pengolahan metode pembelajaran kooperatif model STAD, dan lembar observasi aktifitas guru dan siswa.

\section{Tahap kegiatan dan pelaksanaan}

Pelaksanaan kegiatan belajar mengajar untuk siklus I dilakasanakan pada tanggal 5 Juli 2008 di Kelas IX SMP Negeri 1 Paciran dengan jumlah siswa 30 siswa. Pelaksanaan metode pembelajaran kooperatif model STAD melalui tahapan sebagai berikut : (1) Pelaksanaan pembelajaran, (2) Diskusi kelompok, (3) Tes, (4) Penghargaan kelompok, (5) Menentukan nilai individual dan kelompok. Dalam hal ini peneliti bertindak sebagai pengajar, sedangkan yang bertindak sebagai pengamat adalah seorang guru Matematika dan Wali Kelas IX. Adapun proses belajar mengajar mengacu pada rencana pelajaran yang telah dipersiapkan. Pengamatan (observasi) dilaksanakan bersamaan dengan pelaksanaan dengan pelaksanaan belajar mengajar.

Pada akhir proses belajar mengjaar siswa diberi tes formatif I dengan tujuan untuk mengetahui tingkat keberhasilan siswa dalam proses belajar mengajar yang telah dilakukan. Adapun data hasil penelitian pada siklus I menunjukkan bahwa aspek-aspek yang mendapatkan kriteria kurang baik adalah memotivasi siswa, menyampaikan tujuan pembelajaran, pengelolaan waktu, dan siswa antusias. Keempat aspek yang mendapat nilai kurang baik di atas, merupakan suatu kelemahan yang terjadi pada siklus I dan akan dijadikan bahan kajian untuk refleksi dan revisi yang akan dilakukan pada siklus II.

Hasil observasi berikutnya adalah aktivitas guru dan siswa. Hasil observasi menunjukkan bahwa aktivitas guru yang paling dominan pada siklus I adalah membimbing dan mengamati siswa dalam menemukan konsep, yaitu 21,7 \%. Aktivitas lain yang presentasinya cukup 
besar adalah memberi umpan balik/ evaluasi, tanya jawab dan menjelaskan materi yang sulit yaitu masing-masing sebesar 13,3 \%. Sedangkan aktivitas siswa yang paling dominan adalah mengerjakan/ memperhatikan penjelasan guru yaitu 22,5\%. Aktivitas lain yang presentasinya cukup besar adalah bekerja dengan sesama anggota kelompok, diskusi antara siswa/ antara siswa dengan guru, dan membaca buku yaitu masingmasing $18,7 \% 14,4$ dan $11,5 \%$.
Pada siklus I, secaraa garis besar kegiatan belajar mengajar dengan metode pembelajaran kooperatif model STAD sudah dilaksanakan dengan baik, walaupun peran guru masih cukup dominan untuk memberikan penjelasan dan arahan, karena model tersebut masih dirasakan baru oleh siswa.

Berikutnya dalah rekapitulasi hasil tes formatif siswa seperti terlihat pada tabel berikut.

Tabel 1 Rekapitulasi Hasil Tes Ulangan Harian / Blok Siswa Pada Siklus I

\begin{tabular}{|c|l|c|}
\hline No & \multicolumn{1}{|c|}{ Uraian } & Hasil Siklus I \\
\hline 1 & Nilai rata-rata tes formatif & 6,79 \\
2 & Jumlah siswa yang tuntas belajar & 26 \\
3 & Presentase ketuntasan belajar & 68,2 \\
\hline
\end{tabular}

Dari tabel di atas dapat dijelaskan bahawa dengan menerapkan metode pembelajaran kooperatif model STAD diperoleh nilai rata-rata prestasi belajar siswa adalah 6,79 dan ketuntasan belajar mencapai $68,42 \%$ atau ada 21 siswa dari 30 siswa sudah tuntas belajar. Hasil tersebut menunjukkan bahawa paa siklus pertama secaraa klasikal siswa belum tuntas belajar, karena siswa yang memperoleh nilai $\geq 65$ hanya sebesar $68,42 \%$ lebih kecil dari presentase ketuntasan yangt dikehendaki yaitu sebesar $85 \%$. Hal ini disebabkan akrena siswa masih merasa baru dan belum mengerti apa yang dimaksudkan dan digunakan guru dengan menerapkan metode pembelajaran kooperatif model STAD.

\section{Refleksi}

Dalam pelaksanaan kegiatan belajar mengajar diperoleh informasi dari hasil pengamatan sebagai berikut :

1) Guru kurang maksimal dalam memotivasi siswa dan dalam menyampaikan tujuan pembelajaran.
2) Guru kurang/ belum maksimal dalam pengelolaan waktu

3) Siswa kurang aktif selama pembelajaran berlangsung

Analisis data penelitian siklus I

\section{Ranah Psikomotor}

1. Siswa yang mendapat nilai 60 tidak ada

2. Siswa yang mendapat nilai 70 sebanyak $12(38,46 \%)$

3. Siswa yang mendapat nilai 80 sebanyak $18(61,54 \%)$

4. Berarti siswa yang mendapat nilai di atas 70 sebanyak $61,54 \%$, secaraa klasikal termasuk kategori belum tuntas.

\section{Ranah Afektif}

- Siswa mendapat nilai C sebanyak 4 $(15,38 \%)$

- Siswa yang mendapat nilai B sebanyak $20(66,67 \%)$

- Siswa yang mendapat nilai A sebanyak $6(17,95 \%)$

Berarti siswa yang mendapat nilai di atas C sebanyak $84,62 \%$, secaraa klasikal termasuk kategori tuntas. 


\section{Revisi}

Pelaksanaan kegiatan belajar mengajar pada siklus I ini masih terdapat kekurangan, sehingga perlu adanya revisi untuk ilakukan pada siklus berikutnya.

1) Guru perlu lebih terampil dalam memotivasi siswa dan lebih jelas dalam menyampaikan tujuan pembelajaran. Dimana siswa diajak untuk terlibat langsung dalam setiap kegiatan yang akan dilakukan.

2) Guru perlu mendistribusikan waktu secara baik dengan menambahkan informasi-informasi yang dirasa perlu dan memberi catatan

3) Guru harus lebih terampil dan bersemangat dalam memotivasi siswa sehingga siswa bisa lebih antusias.

\section{Siklus II}

\section{Tahap perencanaan}

Pada tahap ini peneliti mempersiapkan perangkat pembelajaran yang terdiri ari rencana pelajaran 2 , soal tes formatif 2 dan alat-alat pengajaran yang mendukung. Selain itu juga dipersiapkan lembar observasi pengelolaan metode pembelajaran kooperatif model STAD dan lembar observasi guru dan siswa.

\section{Tahap kegiatan dan pelaksanaan}

Pelaksanaan kegiatan belajar mengajar untuk siklus II dilaksanakan pada tanggal 10 Agustus 2008 di Kelas IX SMP Negeri 1 Paciran dengan jumlah siswa 30 siswa. Pelaksanan metode pembelajaran kooperatif model STAD melalui tahapan sebagai berikut; (1) Pelaksanaan pembelajran, (2) Diskusi klompok, (3) Tes, (4) Penghargaan kelompok, (5) Menentukan nilai individual dan kelompok. Dalam hal ini peneliti bertindak sebagai pengajar, sedangkan yang bertindak sebagi pengamat adalah seorang guru
Matematika dan Wali Kelas IX SMP Negeri 1 Paciran Adapun proses belajar mengajar mengacu pada rencana pelajaran dengan memperhatikan revisi pada siklus I, sehingga kesalahan atau kekurangan pada siklus I tidak terulang lagi pada siklus II. Pengamatan (observasi) dilaksanakanbersamaan dengan pelaksanaan belajar mengajar.

Pada akhir proses belajar mengajar siswa diberi tes formatif II dengan tujuan untuk mengetahui tingkat keberhasilan siswa dalam proses belajar mengajar yang telah dilakukan. Instrument yang digunakan adalah tes formatif II. Adapun data hasil penelitian pada siklus II menunjukkan bahwa aspek-aspek yang diamati pada kegiatan belajar mengajar (siklus II) yang dilaksanakn oleh guru dengan menerapkan metode pembelajaran kooperatif model STAD mendapatkan penilaian yang cukup baik dari pengamat. Maksudnya dari seluruh penilaian tidak terdapat nilai kurang. Namun demikian penilaian tesebut belum merupakan hasil yang optimal, untuk itu ada beberapa aspek yang perlu mendapatkan perhatian untuk penyempurnaan penerapan pembelajaran selanjutnya. Aspek-aspek tersebut adalah memotivasi siswa, membimbing siswa merumuskan kesimpulan/ menemukan konsep, dan pengelolaan waktu.

Dengan penyempurnaan aspekaspek I atas alam penerapan metode pembelajarn kooperatif model STAD diharapkan siswa dapat menyimpulkan apa yang telah mereka pelajari dan mengemukakan pendapatnya sehingga mereka akan lebih memahami tentang apa ynag telah mereka lakukan.

Hasil observasi akivitas guru yang paling dominan pada siklus II adalah membimbing dan mengamati siswa dalam menentukan konsep yaitu $25 \%$. Jika dibandingkan dengan siklus I, aktivitas ini mengalami peningkatan. Aktivitas guru yang mengalami 
penurunan adalah memberi umpan balik/evaluasi/ Tanya jawab (16,6\%), mnjelaskan materi yang sulit $(11,7)$. Meminta siswa mendiskusikan dan menyajikan hasil kegiatan $(8,2 \%)$, dan membimbing siswa merangkum pelajaran $(6,7 \%)$.

Sedangkan untuk aktivitas siswa yang paling dominan pada siklus II adalah bekerja dengan sesama anggota kelompok yaitu (21\%). Jika dibandingkan dengan siklus I, aktifitas ini mengalami peningkatan. Aktifitas siswa yang mengalami penurunan adalah mendengarkan/memperhatikan penjelasan guru $(17,9 \%)$. Diskusi antar siswa/ antara siswa dengan guru $(13,8 \%)$, menulis yang relevan dengan KBM $(7,7 \%)$ dan merangkum pembelajaran $(6,7 \%)$. Adapun aktifitas siswa yang mengalami peningkatan adalah membaca buku (12,1\%), menyajikan hasil pembelajaran $(4,6 \%)$, menanggapi/mengajukan pertanyaan/ide $(5,4 \%)$, dan mengerjakan tes evaluasi $(10,8 \%)$.

Berikutnya adalah rekapitulasi hasil tes formatif siswa terlihat pada tabel berikut :

Tabel 2. Rekapiltulasi Hasil Tes Ulangan Harian / Blok Siswa Pada Siklus II

\begin{tabular}{|c|l|c|}
\hline No & \multicolumn{1}{|c|}{ Uraian } & Hasil Siklus I \\
\hline 1 & Nilai rata-rata tes formatif & 7,29 \\
2 & Jumlah siswa yang tuntas belajar & 31 \\
3 & Presentase ketuntasan belajar & 81,58 \\
\hline
\end{tabular}

Dari tabel diatas diperoleh nilai rata-rata prestasi belajar siswa adalah 7,29 dan ketuntasan belajar mencapai $81,58 \%$ atau ada 24 siswa dari 30 siswa sudah tuntas belajar. Hasil ini menunjukkan bahwa pada siklus II ini ketuntasan belajar secaraa klasikal telah mengalami peningkatan sedikit lebih baik dari siklus I. Adanya peningkatan hasil

belajar siswa ini karena setelah guru

menginformasikan bahaw setiap akhir pelajaran akan selalu diadakan tes sehingga pada pertemuan berikutnya siswa lebih termotivasi untuk belajar. Selain itu siswa juga sudah mulai mengerti apa yang dimaksudkan dan diinginkan guru dengan menerapkan metode pembelajarn kooperatif model STAD.

\section{Analisis data penelitian Siklus I \\ Ranah Psikomotor}

- Siswa yang mendapat nilai 60 tidak ada

- Siswa yang mendapat niali 70 sebanyak $12(38,46 \%)$
- Siswa yang mendapat nilai 80 sebanyak $18(61,54 \%)$

Berarti siswa yang mendapat nilai di atas 70 sebanyak $61,54 \%$, secaraa klasikal termasuk kategori belum tuntas.

\section{Ranah Afektif}

Siswa yang mendapat nilai $\mathrm{C}$ sebanyak $4(15,38 \%)$

Siswa yang mendapat nilai B sebanyak

$20(66,67 \%)$

Siswa yang mendapat nilai A sebanyak $6(17,95 \%)$

Berarti siswa yang mendapat nilai di atas C sebanyak $84,62 \%$, secaraa klasikal termasuk kategori tuntas.

\section{Refleksi}

Dalam pelaksanaan kegiatan belajar diperoleh informasi dari hasil pengamatan sebagai berikut :

1) Memotivasi siswa

2) Membimbing siswa merumuskan kesimpulan/menemukan konsep

3) Pengelolaan waktu 


\section{Revisi Rancangan}

Pelaksanan kegiatan belajar pada Siklus II ini masih terdapat kekurangankekurangan. Maka perlu adanya revisi untuk dilaksanakan pada siklus II antara lain :

1. Guru dalam memotivasi siswa hendaknya dapat membuat siswa lebih termotivasi selama proses belajar mengajar berlangsung.

2. Guru harus lebih dekat dengan siswa sehingga tidak ada perasaan takut dalam diri siswa baik untuk mengemukakan pendapat atau bertanya.

3. Guru harus lebih sabar dalam membimbing siswa merumuskan kesimpulan/menemukan konsep.

4. Guru harus mendistribusikan waktu secaraa baik sehingga kegiatan pembelajaran dapat berjalan sesuai dengan yang diharapkan.

5. Guru sebaiknya menambah lebih banyak contoh soal dan meberi soalsoal-soal latihan pada siswa untuk dikerjakan pada setiap kegiatan belajar mengajar.

\section{Siklus III}

\section{Tahap Perencanaan}

Pada tahap ini peneliti mempersiapkan perangkat pembelajaran yang terdiri dari rencana pelajaran 3, soal tes formatif 3 dan alat-alat pengajaran yang mendukung. Selain itu juga dipersiapkan lembar observasi pengelolaan metode pembelajaran kooperatif model STAD dan lembar observasi aktifitas guru dan siswa.

\section{Tahap Kegiatan dan Pengamatan}

Pelaksanaan kegiatan belajar mengajar untuk siklus III dilaksanakan pada tanggal 5 September 2008 di kelas IX SMP Negeri 1 Paciran dengan jumlah siswa 30 siswa. Pelaksanaan metode pembelajaran kooperatif model STAD melalui tahapan sebagai berikut: (1) Pelaksanaan pembelajaran, (2) Diskusi kelompok, (3) Tes, (4) Penghargaan kelompok, (5) Menentukan nilai individual dan kelompok. Dalam hal ini peneliti bertindak sebagai pengajar, sedangkan yang bertindak sebagai pengamat adalah seorang guru Matematika dan Wali Kelas IX SMP Negeri 1 Paciran Adapun proses belajar mengajar mengacu pada rencana pelajaran dengan memperhatikan revisi pada siklus II, sehingga kesalahan atau kekurangan pada siklus II tidak terulang lagi pada siklus III. Pengamatan (observasi) dilaksanakan bersamaan dengan pelaksanaan belajar mengajar.

Pada akhir proses belajar mengajar siswa diberi tes formatif III dengan tujuan untuk mengetahui tingkat keberhasilan siswa dalam proses belajar mengajar yang telah dilakukan. Instrument yang digunakan adalah tes formatif III dengan tujuan untuk mengetahui tingkat keberhasilan siswa dalam proses belajar mengajar yang telah dilakukan. Instrument yang digunakan adalah tes formatif III. Adapun data hasil penelitian pada siklus III dapat dilihat dari aspek-aspek yang diamati pada kegiatan belajar mengajar (siklus III) yang dilaksanakan oleh guru dengan menerapkan metode pembelajaran kooperatif model STAD mendapatkan penilaian cukup baik dari pengamat adalah memotivasi siswa, membimbing siswa merumuskan kesimpulan/ menemukan konsep, dan pengelolaan waktu.

Penyempurnaan aspek-aspek diatas dalam menerapkan metode pembelajaran kooperatif model STAD diharapkan dapat berhasil semaksimal mungkin. 
Tabel 3. Aktivitas Guru dan Siswa Pada Siklus III

\begin{tabular}{|c|l|c|}
\hline No & \multicolumn{1}{|c|}{ Aktivitas Guru yang diamati } & Presentase \\
\hline & Menyampaikan tujuan & \\
2 & Memotivasi siswa & 6,7 \\
3 & Mengkaitkan dengan pelajaran sebelumnya & 6,7 \\
4 & Menjelaskanan materi yang sulit & 10,7 \\
5 & Membimbing dan mengamati siswa dalam & 13,3 \\
6 & menemukan konsep & 10,0 \\
7 & Meminta siswa menyajikan dan mendiskusikan hasil & 22,6 \\
8 & kegiatan & 10,0 \\
9 & Memberikan umpan balik & 11,7 \\
& Membimbing siswa merangkum pelajaran & 10,0 \\
\hline No & \multicolumn{1}{|c}{ Aktivitas siswa yang diamati } & Presentase \\
\hline 1 & Mendengarkan/memperhatikan penjelasan guru & 20,8 \\
2 & Membaca buku & 13,1 \\
3 & Bekerja dengan sesama anggota kelompok & 22,1 \\
4 & Diskusi antar siswa/ antara siswa dengan guru & 15,0 \\
5 & Menyajikan hasil pembelajaran & 2,9 \\
6 & Menyajikan/menanggapi pertanyaan/ide & 4,2 \\
7 & Menulis yang relevan dengan KBM & 6,1 \\
8 & Merangkum pembelajaran & 7,3 \\
9 & Mengerjakan tes evaluasi & 8,5 \\
\hline
\end{tabular}

Berdasarkan tabel diatas tampak bahaw aktivitas guru yang paling dominan pada siklus III adalah membimbing dan mengamati siswa dalam menemukan konsep yaitu 22,6\%, sedangkan aktivitas menjelaskan materi yang sulit dan memberi umpan balik/evaluasi/tanya jawab menurun masing-masing sebesar (10\%), dan $(11,7 \%)$. Aktivitas lain yang mengalami peningkatan adalah mengkaitkan dengan pelajaran sebelumnya (10\%), menyampiakan materi/strategi /langkahlangkah (13,3\%), meminta siswa menyajikan dan mendiskusikan hasil kegiatan (10\%), dan membimbing siswa merangkum pelajaran (10\%). Adapun aktivitas ynag tidak menglami perubahan adalah menyampaikan tujuan $(6,7 \%)$ dan memotivasi siswa $(6,7 \%)$.

Sedangkan untuk aktivitas siswa yang paling dominan pada siklus III adalah bekerja dengan sesama anggota kelompok yaitu $(22,1 \%)$ dan mendengarkan/memperhatikan penjelasan guru $(20,8 \%)$, aktivitas yang mengalami peningkatan adalah membaca buku siswa $(13,1 \%)$ dan diskusi antar siswa/antara siswa dengan guru $(15,0 \%)$. Sedangkan aktivitas yang lainnya mengalami penurunan.

Berikutnya adalah rekapitukasi hasil tes formatif siswa seperti terlihat pada tabel berikut.

Tabel 4 Rekapiltulasi Hasil Tes Ulangan Harian / Blok Siswa Pada Siklus III

\begin{tabular}{|c|l|c|}
\hline No & \multicolumn{1}{|c|}{ Uraian } & Hasil Siklus III \\
\hline 1 & Nilai rata-rata tes formatif & 7,97 \\
2 & Jumlah siswa yang tuntas belajar & 36 \\
3 & Presentase ketuntasan belajar & 94,74 \\
\hline
\end{tabular}


Berdasarkan tabel di atas diperoleh nilai rata-rata tes formatif sebesar 7,97 dan dari 30 siswa yang telah tuntas sebanyak 26 siswa dan 4 siswa belum mencapai ketuntasan belajar. Maka secara klasikal ketuntasan belajar yang telah tercapai sebesar $94,74 \%$ (termasuk kategori tuntas). Hasil pada siklus III ini mengalami peningkatan lebih baik dari siklus II. Adanya peningkatan hasil belajar pada siklus III ini di pengaruhi oleh adanya peningkatan kemampuan guru dalam menerapkan metode pembelajaran kooperatif moel STAD sehingga siswa menjadi lebih terbiasa dengan pembelajaran seperti ini sehingga siswa lebih mudah dalam memahami materi yang telah diberikan.

\section{Refleksi}

Pada tahap ini akan dikaji apa yang telah terlaksana dengan baik maupun yang masih kurang baik dalam proses belajar mengajar dengan penerapan metode pembelajaran kooperatif model STAD. Dari data-data yang telah diperoleh dapat diuraikan sebagi berikut:

1) Selama proses belajar mengajar guru telah mekasanakan semua pembeljaran dengan baik. Meskipun ada beberapa aspk yang belum sempurna, tetapi presentase pelaksanaanya untuk masing-masing aspek cukup besar.

2) Berdasarkan data hasil pengamatan diketahui bahwa siswa aktif selama proses belajar mengajar berlangsung.

3) Kekurangan pada siklus-siklus sebeelumnya sudah mengalami perbaikan dan peningkatan sehingga menjadi lebih baik.

4) Hasil belajar siswa paa siklus III mencapai ketuntasan.

\section{Revisi Pelaksanaan}

Pada siklus III guru telah menerapkan metode pemebelajaran kooperatif model STAD dengan baik dan dilihat dari kativitas siswa serta hasil belajar siswa pelaksanaan proses belajar mengajar sudah berjalan dengan baik. Maka tidak diperlukan revisi terlalu banyak, tetapi yang perlu diperhatikan untuk tindakan selanjutnya adalah memaksimalkan dan mempertahankan apa yang telah ada dengan tujuan agar pelaksanaan proses belajar mengajar selanjutnya penerapan metode pembelajaran kooperatif model STAD dapat meningkatkan proses belajar mengajar, sehingga tujuan pembelajaran dapat tercapai.

\section{Pembahasan}

\section{Ketuntasan hasil belajar siswa}

Melalui hasil penelitian ini menunjukkan bahawa metode pembelajran kooperatif model STAD memiliki dampak positif dalam meningkatkan prestasi belajar siswa. Hal ini dapat dilihat dari semakin mantapnya pemahaman siswa terhadap materi yang disampaikan guru (ketuntasanbelajar meningkat dari siklus I, II, dan III) yaitu masing-masing $68,2 \%, 81,58 \%$ dan 94,74\%. Pada siklus III ketuntasan belajar siswa secara klasikal telah tercapai. Sedangakan kelompok yang mendapatkan penghargaan adalah kelompok I dengan nilai kelompok tertinggi sebesar 6,17.

\section{Kemampuan Guru Dalam Mengelola Pembelajaran}

Berdasarkan analisis data, diperoleh aktifitas siswa dalam proses belajar mengajar dengan menerapkan metode pembelajaran kooperatif model STAD dalam setiap siklus mengalami peningkatan. Hal ini berdampak positif terhadap prestasi belajar siswa yaitu dapat ditunjukkan dengan meningkatnya nilai rata-rata siswa pada setiap siklus yang terus mengalami peningkatan. 


\section{Aktivitas Guru dan Siswa Dalam Pembelajaran}

Berdasakan analisi data, diperoleh aktifitas siswa dalam proses pembelajran Matematika pada pokok bahasan Kesebangunan bangun datar dengan metode pembelajaran kooperatif model STAD yang paling dominan adalah bekerja dengan sesama anggota kelompok, mendengarkan/ memperhatikan penjelasan guru dan iskusi antar siswa /antara siswa dengan guru. Jadi dapat dikatakan bahawa aktifitas siswa dikategorikan aktif.

Sedangkan untuk aktifitas guru selama pembelajaran telah melaksanakan langkah-langkah kegiatan belajar mengajar dan menerapkan pengajaran konstektual model pengajaran berbasis maslah dengan baik. Hal ini terlihat dari aktivitas guru yang muncul, diantaranya aktivitas membimbing dan mengamati siswa dalam menemukan konsep, menjelaskan materi yang sulit, memberi umpan balik/ evaluasi/ tanya jawab dimana prosentase untuk aktivitas di atas cukup besar.

\section{SIMPULAN DAN SARAN Simpulan}

Berdasarkan hasil penelitian yang telah dipaparkan selama tiga siklus, hasil seluruh pembahasan serta analisis yang telah dilakukan dapat disimpulkan sebagai berikut :

1. Metode pembelajaran kooperatif model STAD dapat meningkatkan kualitas pembelajaran Matematika

2. Metode pembelajaran kooperatif model STAD memiliki dampak positif dalam meningkatkan prestsi belajar siswa yang ditandai dengan peningkatan ketuntasan belajar siswa dalam setiap siklus, yaitu siklus I $(68,42 \%)$, siklus II $(81,58 \%)$, siklus III $(94,74 \%)$.

3. Metode pembelajaran kooperatif model STAD dapat menjadikan siswa merasa dirinya mendapat perhatian dan kesempatan untuk menyampaikan pendapat, gagasan, ide, dan pertanyaan.

4. Siswa dapat bekerja secara mandiri maupun kelompok, serta mampu mempertanggungjawabkan tugas individu maupun kelompok.

5. Penerapan metode pembelajaran kooperatif model STAD mempunyai pengaruh positif, yaitu dapat meningkatkan motivasi belajar siswa.

\section{Saran}

Dari hasil penelitian yang diperoleh dari uraian sebelum agar proses belajar mengajar Matematika lebih efektif dan lebih memberikan hasil yang optimal bagi siswa, maka disampaikan saran sebagai berikut :

1. Untuk melaksanakan metode pembelajaran kooperatif model STAD memerlukan persiapan yang cukup matang, sehingga guru harus mampu menentukan atau memilih topik yang benar-benar bisa diterapkan dengan Metode pembelajaran kooperatif model STAD dalam pross belajar mengajar sehingga memperoleh hasil yang optimal.

2. Dalam rangka meningkatkan prestasi belajar siswa, guru hendaknya lebih sering melatih siswa dengan berbagai metode pengajaran, walau dalam taraf yang sederhana, dimana siswa nantiny dapat menemukan pengetahuan baru, memperoleh konsep dan keterampilan, sehingga siswa berhasil atau mampu memecahkan masalah-masalah yang dihadapi.

3. Perlu adanya penelitian yang lebih lanjut, karena hasil penelitian ini hanya dilakukan di SMP Negeri 1 Paciran tahun pelajaran 2008 - 2009.

4. Untuk peneltian yang serupa hendaknya dilakukan perbaikanperbaikan agar diperoleh hasil yang lebih baik. 
DAFTAR PUSTAKA

Ali, Muhammad. 1996. Guru Dalam Proses Belajar Mengajar. Bandung: Sinar Baru Algesindon .

Arikunto, Suharsimi. 1993. Manajemen Mengajar Secara Manusiawi. Jakarata: Rineksa Cipta

Arikunto, Suharsimi. 2001.Dasar-dasar Evaluasi Pendidikan. Jakarta: Bumi Aksara

Arikunto, Suharsimi. 2002. Prosedur Penelitian Suatu Pendekatan Praktek. Jakarta: Rineksa Cipta.

Azhar, Lalu Muhammad. 1993. Proses Belajar Mengajar Pendidikan. Jakarta: Usaha Nasional.
Daroeso, Bambang. 1989. Dasar dan Konsep Pendidikan Moral Pancasila. Semarang: Aneka Ilmu.

Felder, Richad M. 1994. Cooperative Learning In The Technical Corse, (online), (PcllldMM\% DocumentlCoop \% 20 Report.

Hadi, Sutrisno. 1982. Metodologi Research, Jilid I.yogayakarta: yp. Fak. Psikologi UGM.

Sukidin dkk. 2002. Manajemen Penelitian Tindakan Kelas. Surabaya: Insane Cendekia. 